\title{
The Impact of Macroeconomic Variables and Banks Characteristics on Jordanian Islamic Banks Profitability: Empirical Evidence
}

\author{
Ali Mustafa Al-Qudah ${ }^{1} \&$ Mahmoud Ali Jaradat ${ }^{2}$ \\ ${ }^{1}$ Department of Finance and Business Economics, Faculty of Finance and Business Administration, Al Al-Bayt \\ University, Jordan \\ ${ }^{2}$ Department of Banking and Finance, Faculty of Finance and Business Administration, Al Al-Bayt University, \\ Jordan \\ Correspondence: Ali Mustafa Abdullah Al-Qudah, Department of Finance and Business Economics, Faculty of \\ Finance and Business Administration, Al Al-Bayt University, Al Mafraq, Jordan. E-mail: alimqf@yahoo.com
}

Received: May 13, 2013

Accepted: July 16, 2013

Online Published: September 23, 2013

doi:10.5539/ibr.v6n10p153

URL: http://dx.doi.org/10.5539/ibr.v6n10p153

\begin{abstract}
The aim of this study is to determine the effect of macroeconomic Variables (external variables) and bank characteristic (internal variables) on the profitability of Jordanian Islamic banks for the period (2000-2011).the study used panel data analysis fixed effects model and the generalized least square method to examine the study hypotheses. The empirical analysis shows that capital adequacy, bank size have a positive and significant impact on return on assets (ROA) and return on equity (ROE). While leverage measured by total deposit to total assets has a negative and significant impact on (ROA) and (ROE). The liquidity has an inersary insignificant effect on (ROA) and negative significant impact on (ROE). The study found that macroeconomic factors represented by Amman stock exchange index, construction licensed square meters and money supply growth are good determinants for Islamic banks profitability.
\end{abstract}

Keywords: macroeconomic variables, banks characteristics, Islamic banks, Jordan, profitability, panel data

\section{Introduction}

Islamic banking system is fifty years old and it is a part of banking system. Since the first Islamic bank has been established at the beginning of the 1960s in Egypt, and the activity of Islamic banking growing steadily since the beginning of the 1970s all over the world, during eighties of the twentieth century. The Islamic banking system witnessed a main great growth. The major progress was the foundation of Islamic and Training Institute by Islamic Development Bank in Jeddah to conduct research at the practical and theoretical level. Bahrain and Malaysia are examples of the countries which encourage Islamic banking. The banking systems were converted to noninterest banks in Iran, Pakistan, and Sudan. In addition, western commercial banks began to provide Islamic products through what is known as Islamic windows (Greuning \& Iqbal, 2008).

In the 1990s the Islamic banking industry was growing progressively more. In the first decade of the new century Islamic banking was considered as one of the greatest developing financial sector in the world (Booz \& Company, 2008). The Kuwait Finance House expected that Islamic banking will continue to grow worldwide, driven by growth factors and increasing demand. Islamic banking assets are expected to reach US\$ 1.5 trillion by the end of the 2013 year with an accumulative growth rate of up to $20 \%$.

It is worth mentioning that Jordan Islamic Bank was established in 1973 as the first Islamic bank in Jordan, followed by the Islamic International Arab Bank in 1999, and Jordan Dubai Islamic Bank in 2010, and Al Rajhi Bank in 2011.

According to Islamic legislations and laws Islamic banking is a noninterest system (Alkassim, 2005). Also it is known as banks argue that they apply the Islamic laws in their business transactions and they do not charge any interest (Maali, Casson, \& Napier, 2006).

This study aims to investigate the impact of the macroeconomic and bank characteristics on Jordanian Islamic banks' profitability. The paper is divided into five sections. The literature review is expressed in Section 2. Section 3 shows the methodology used in analysing the relationship between Islamic banks profitability and determinants used in this study. Section 4 is dedicated discussion of the regression results and Section 5 is 
dedicated to the concludes.

\section{Literature Review}

The literature divided the determinants (factors) of banks financial performance in two types (Haron, 2004): the first is the external determinants are those factors that are considered to be away from the control of bank administration such as gross domestic product, conventional banks interest rates, competition, regulation, concentration, market share, ownership and inflation.

The second is the internal determinants of the financial performance, within the control of bank administration, and can be classified into two parts: financial statement variables which relates the balance sheet and income statement while non financial variables which haven't direct relation to financial statements such as size of the bank, bank location, number of branch, age, number of board of directories. Financial variables: many studies examined the impact of financial statement and income statement items on the financial performance of conventional banks those studies found that the change in financial statements items has a significant impact of banks financial performance. Since they found that all assets items had a positive impact on banks financial performance measures, while the liabilities items such as loan rate, time deposit rate, loan to deposit ratio, demand, time and saving deposits, had a negative impact on financial performance measures. Hester and Zoellner (1996), Mullineaux (1978).

Regarding deposit types, Heggested (1977) found that banks depend mainly on time and savings deposits achieved very low returns than banks which mainly depend on demand deposits. Smirlock (1985) confirmed that, and attribute the fact that to demand deposits were a cheaper source of funds and had a positive impact on bank profits. Bourke (1989); Molyneux and Thornton (1992) found that capital ratios, liquidity ratios and staff expenses had a positive impact on profitability.

\subsection{Empirical Evidence}

1) Noor and Ahmad (2011) examined the efficiency of the 78 Islamic banks in 25 countries for the period 1992-2009. The Fixed Effect Model used to examine the impact of operating expenses to assets, equity, high income countries and non-performing loans to total loans on profit efficiency. They found that the operating expenses to assets, more equity to assets and high income countries, have a positive and significant effect on financial performance of Islamic banks

2) Asma, Fadi and Noor (2011) examined the determinants of profitability of Islamic banks in Malaysia. A number of Islamic banks specifics variables had been used such as capital adequacy, and management of expenses credit risk, liquidity, Log total assets. They found that only the bank's size has a positive significant impact on profitability of Malaysian Islamic banks. While the other variables have no impact on Islamic's banks profitability.

3) Bashir (2003) investigated the determinants of profitability for 14 Islamic Banks from 8 Middle Eastern Countries. He found that total equity to total assets, loans to total assets and overhead (salaries, wages, and investment cost) have a positive and significant impact on profitability measured by (ROA), (ROE) and basic earning power. Gross domestic product growth has a positive and significant impact on Islamic banks profitability.

4) Bashir and Hassan (2000) examined the impact of bank characteristics on Islamic banks financial performance. They found that profitability is positively related to equity to total assets, and inversely related to loans ratios. Also, they found that growth has a positive and significant effect on the financial performance of Islamic banks.

5) Izhar and Asutaya (2007) investigated the determinants of profitability of Islamic banks in Indonesia. They found that the non-interest earning had no statistically significant impact on the profitability of Islamic banks in Indonesia. While they found that inflation had a positive significant impact on profitability of Indonesian Islamic banks.

6) Alkassim (2005) examined the financial performance of 34 Islamic and conventional banks in Gulf countries during the period of 1997-2004. By using multiple linear regression. The study used three financial performance indicators measures return on equity, return on assets, and net interest margin, and six internal variables such as bank's size, total equity to total assets, total loans against total assets, deposits against total assets, total expenses against total asset, and non-interest expense against total expense. They found that, bank's size, total equity and total expenses have an inverse effect on traditional banks' profitability, while they have a positive effect on Islamic banks financial performance. Total loans have positive impact on Islamic and conventional banks performance. Deposits have a positive effect on conventional banks, but have an inverse effect on Islamic banks performance. 
7) Haron (2004) investigated the factors that effect Islamic banks financial performance. He found that liquidity, total expenditures, funds invested in Islamic securities, size of the bank and the percentage of the profit-sharing ratio between the bank and the borrower of funds have a positive and significant impact on total income received by the Islamic banks. The macroeconomic factors such as interest rates and market share also, have a positive and significant impact on the financial performance of Islamic banks. Other variables such as current accounts, total capital and reserves, have a significant effect on the profitability of Islamic banks.

The literature reveals the following research gaps. Almost nothing has been published to examine the impact of stock exchange index on the Islamic banking sector. Construction licensed square meters and money supply growth (M2) growth, In the light of these knowledge gaps, the present study provides new empirical evidence on the impact of stock exchange index, Construction licensed square meters and money supply in the wide concept (M2) growth on the performance of Jordanian Islamic banks.

\section{The Sample and Methodology}

\subsection{The Sample}

The study used a sample of all Jordanian Islamic banks (Jordan Islamic Bank and Arab International Islamic Bank) while the two other banks (Jordan Dubai Islamic Bank and the Al Rajhi Bank) are excluded from the study because they do not have enough since they started their work in Jordan in 2010 and 2011 respectively. The study covered the period 2000-2011. The present study chose the Islamic banks to examine the factors that impact their performance because they play a great role in the Jordanian economy.

The source of the data used in the present study is the data base of Amman stock exchange and the data base central bank of Jordan.

\subsection{Methodology}

In order to achieve the above mentioned objectives, the panel data has been used to carry out the empirical analysis on determinants of the profitability Jordanian Islamic banks that come from financial statements, in other words financial ratios and macroeconomic variables are employed to examine the study hypotheses.

\subsubsection{Dependent Variables}

Bank profitability has been used to determine the bank's financial performance.

a. Return on Assets (ROA): return on assets is net income to total assets. ROA is a good indicator of bank's financial performance and managerial efficiency. The higher ratio of (ROA) expresses an efficient use of assets of the bank and better managerial performance while a lower ratio means inefficient use of assets (Samad, 2004).

b. Return on Equity (ROE): return on equity is the profitability indicator that is the net income to total equity. ROE is the ratio that is a sign of profitability generated from the amount capital that shareholders invested. This ratio tells us that how efficient a bank is able to generate profit from the money that had been invested by shareholders. The higher the ratio of (ROE) expresses an efficient use of equity of the firm and better managerial performance (Samad, 2004).

\subsubsection{Independent Variables}

Bank characteristics:

We follow Haron (2004) in our definition of internal variables.

a. Capital adequacy is the total equity to total assets (TETA): It measures the proportion of total assets which is being financed by shareholders. It is the ability survive to any unexpected loses and bankruptcy. Capital ratio is an important tool for assessing safety and soundness of banks. Vong and Chan, (2009) wrote in the content, the bank with high capital ratio or more equity capital is showing that the bank is safer and is more able to get higher profitability.

b. Liquidity is measured by total loans to total deposits (TLTD): It indicates the percentage of bank's loans funded through deposits. Liquidity measures the ability of an organization to meet its obligations and the solvency of organization (Khan \& Jain, 2008).

c. Leverage measured by total deposit to total assets (TDTA): Leverage means magnification of either profits or losses. Leverage represents metrics tool to determine the possibility of the inability of the firm to pay its debts, particularly in the long term. Therefore, the increase in financial leverage increases the possibility of the firm's exposure to non-financial solvency and bankruptcy. In spite of the importance of using debt in the financing structure because the debt interest achieved a tax shed advantage for the company, but they may cause a conflict of interests of creditors and owners, since creditors are looking for low-risk investments while investors are 
looking for profitable investments. Financial leverage happened when an organization uses short or long term debt to magnify profits (Booth \& Seen Clearly, 2008).

Financial Structure Indicator:

a. Bank size is measured by the logarithmic of the total assets (LTA): the total assets are the absolute number in the balance sheet which consists of short term funding and long-term funding and that why logarithmic of total assets is taken to conduct the regression analysis. Large size is expected to promote economies of scale and reduce the cost of gathering and processing information (Boyd \& Runkle, 1993). In general, large-sized banks have the advantage of providing a larger number of financial services to their customers, and hence activate more funds (Bashir, 1999).

Macroeconomic variables:

a. Logarithmic of Amman stock Exchange index (LSMI): Developed stock markets provide two advantages for listed companies: first, providing information second, reducing capital constraints by selling or buying their shares in the stock exchange (Allen, 1993; Jensen, 1989; Faure-Grimaud \& Gromb, 2004).

b. Logarithimic of construction licensed square meters: the construction sector is considered as one of the important sectors in the Jordan economy as well as its important for Islamic banks operation since one of the main functions of Islamic banks is financing construction projects both for households and investors, through Murabaha and Ijarah. Since Ijarah is a contract that is used to lend or hire or lease ant commodity such as, equipment, machines, building, flats, and even land. As property, is being leased by clients that leasing ending with ownership to the lessee (Haron \& Nursofiza, 2009).

c. Broader money supply growth (GM2): Money supply is a measure of the total amount of money in an economy. Money supply (M2) is the summation of currency in circulation, demand deposit, time deposit and saving deposit.

Table 1. Description of dependent and independent variables

\begin{tabular}{ll}
\hline Variable & Description \\
\hline ROA & Return on assets(net income to total assets \\
ROE & Return on equity(net income to total equity) \\
Capital Adequacy (TETA) & Total equity to total assets \\
Bank Size (LTA) & The logarithmic of total assets \\
TDTA & Total deposit to total assets \\
Liquidity (TLTD) & total loans to total deposits \\
LSMI & Logarithmic of Amman stock exchange index \\
LCLSM & Logarithmic of construction licensed square meters \\
GM2 & Growth of broader money supply \\
\hline
\end{tabular}

In current study a panel data regression analysis is performed, panel data is a cross section and time series data. A panel data approach is more useful than either cross-section or time-series data alone because it gives many benefits such as controlling for heterogeneity, more useful data, variability, degrees of freedom and efficiency and less collinearity (Baltagi, 2005).

A panel data can be analysed in two methods: fixed and random effects. The fixed effects model has constant slopes overtime but different intercepts according to the cross-sectional unit and it is constant for each unit overtime. Although there are no significant temporal effects, there are significant differences between firms in this type of model. While the intercept in random effects model is random where the random outcome is a function of a mean value plus a random error (Manez, Rochina, \& Sanchis, 2004). Hausman Test at five (5) percent confidence level is usually used to select either fixed or random effects for the analysis of panel regression. The random effect is used if the probability value $(\mathrm{P})$ for chi2 is greater than 0.05 , otherwise the fixed effect becomes the ideal model for the empirical analysis (Torres-Reyna, 2007).

In this paper we used only the fixed effects model because the condition to use the random effects model is the cross section number must be more the number of parameters and the sample of our study has two cross sections 
while we have seven parameters, in spite of that this will not affect the results since scholars such as Baltagi (2000) states that the fixed effects model is an suitable if we are studying the behaviour of a specific set of organisations. Otherwise, the random effects model is suitable if we are taking $\mathrm{N}$ individuals randomly from a large population. In the current study we take all banks that have the same data so it is not randomly sampled.

The panel data analysis model is as follow:

$$
Y_{i t}=\alpha_{i}+\beta_{1} X_{i t}+U_{i t}
$$

Where $\mathrm{Y}$ represents the dependent variable (Return on assets (ROA), Return on equity (ROE). i bank, $t$ time; $\alpha i$ is the individual effect that which reflect the bank specifications. $\mathrm{X}$ is a vector of explanatory variables (total equity to total assets (TETA), total loans to total deposits (TLTD) total deposits to total assets (TDTA) $\log$ total assets (LTA), log Amman stock exchange index (LSMI), log constructions licensed square meters (LCLSM) and growth in money supply M2 Level. (GM2): $\beta$ S parameters, and $u$ is a stochastic term that explains the impact of the variables that are not taken into consideration in the model.

\subsubsection{Study Hypotheses}

Depending on the literature review and economic theory the present study examines the following alternative hypotheses:

H1: There is a positive relationship between capital adequacy and Islamic banks profitability.

$\mathrm{H} 2$ : There is a positive relationship between bank size and Islamic banks profitability.

$\mathrm{H} 3$ : There is a negative relationship between leverage and Islamic banks profitability.

H4: There is a negative relationship between liquidity and Islamic banks profitability.

H5: There is a positive relationship between Amman stock exchange index and Islamic banks profitability.

H6: There is a positive relationship between construction licensed square meters and Islamic banks profitability.

H7: There is a positive relationship between money supply growth and Islamic banks profitability.

\section{Regression Analysis}

\subsection{Descriptive Statistics Analysis}

Table 2 tabulate the descriptive statistics of all dependent and independent variables. The mean value of return on assets (ROA) and return on equity (ROE) is (0.008991), (0.090282) respectively, which indicates that profitability is low, the standard deviation for profitability measures (ROA) and (ROE) is $(0.005531),(0.06173)$ respectively, this indicates that profitability measures indicates that the profitability measures are not highly fluctuated. The Islamic banks characteristics factors are more fluctuated than profitability measures.

The mean and standard deviation for macroeconomic factors: log Amman stock exchange index (LSMI), log construction licensed square meters (LCLSM), and growth of broader money supply (GM2) is (3.804909), (0.343279); (6.973163), (0.139384); (0.115208), (0.036207) respectively this shows that (LSMI) is highly fluctuated.

Table 2. Descriptive statistics for two Islamic banks in Jordan for the period 2000-2011.

\begin{tabular}{llllllllll}
\hline & ROA & ROE & TDTA & TLTD & LSMI & LCLSM & SETA & LTA & GM2 \\
\hline Mean & 0.008991 & 0.090282 & 0.800778 & 0.4931 & 3.804909 & 6.973163 & 0.104985 & 8.891021 & 0.115208 \\
Median & 0.0092 & 0.06635 & 0.8534 & 0.4583 & 3.947 & 7.001773 & 0.09518 & 8.929686 & 0.114594 \\
Maximum & 0.019 & 0.2183 & 0.9146 & 1.0013 & 4.228 & 7.11142 & 0.228369 & 9.346553 & 0.172835 \\
Minimum & 0.0014 & 0.0188 & 0.3353 & 0.2776 & 3.124 & 6.691303 & 0.051979 & 8.296278 & 0.058025 \\
Std. Dev. & 0.005531 & 0.06173 & 0.155735 & 0.190005 & 0.343279 & 0.139384 & 0.042561 & 0.299844 & 0.036207 \\
Observations & 22 & 22 & 22 & 22 & 22 & 22 & 22 & 22 & 22 \\
\hline
\end{tabular}




\subsection{Correlation Analysis}

Based on table 3 correlation matrix shows that ROA is positively correlated with (TDTA, LSMI, LCLSM, SETA, LTA and GM2) and the highest correlation between ROA and LSMI. The ROE is positively correlated with all independent variables except TDTA. And the correlation matrix doesn't show any multicollinearity between independent variables.

Table 3. Correlation matrix for all variables dependent and independent variables

\begin{tabular}{|c|c|c|c|c|c|c|c|c|c|}
\hline & ROA & ROE & TDTA & TLTD & LSMI & LCLSM & SETA & LTA & GM2 \\
\hline ROA & 1 & & & & & & & & \\
\hline ROE & 0.804233 & 1 & & & & & & & \\
\hline TDTA & -0.507396 & -0.19095 & 1 & & & & & & \\
\hline TLTD & 0.045686 & -0.108862 & -0.023575 & 1 & & & & & \\
\hline LSMI & 0.397958 & 0.618531 & -0.174949 & 0.332774 & 1 & & & & \\
\hline LCLSM & 0.340923 & 0.534688 & -0.17802 & 0.39641 & 0.414736 & 1 & & & \\
\hline SETA & 0.290812 & -0.24678 & -0.397451 & 0.044176 & -0.358037 & -0.373342 & 1 & & \\
\hline LTA & 0.157931 & 0.558498 & 0.364047 & 0.256361 & 0.54674 & 0.511207 & -0.504867 & 1 & \\
\hline GM2 & 0.306867 & 0.191548 & -0.014815 & -0.210039 & -0.502012 & -0.474521 & 0.373144 & -0.351251 & 1 \\
\hline
\end{tabular}

\subsection{Regression Results Analysis and Discussion}

Table 4 shows the output of regression analysis which is applied on financial ratios of Jordanian Islamic banks in order to explain how changes in bank characteristics and macroeconomic indicators may affect the financial performance of Islamic banks and their returns on asset and on equity.

1) The impact of bank characteristics represented by leverage measured by total deposits to total assets (TDTA): The regression results show that the total deposits to total assets (TDTA) has a negative and significant impact on both return on assets (ROA) and return on equity (ROE). The value of the coefficient is (-.0203) and (-.1505) respectively. This means that total deposits to total assets decreases Islamic banks (ROA) by $2.03 \%$ and (ROE) by $15.05 \%$ when it is increased by $1 \%$ keeping other variables fixed. This is consistent with the results of Alkassim (2005). So risk management is an important element in the banking sector to determine profitability level of banking business. A theory suggests that increase of exposure to credit risk is normally associated with decreased firm profitability. Therefore banks would improve monitoring of credit risk and such policies involve forecasting of future level of risks.

2) The impact of bank characteristics represented by capital adequacy measured by total equity to total assets (TETA): The regression results show that the total equity to total assets (TETA) has a positive and significant impact on both return on assets (ROA) and return on equity (ROE). The value of the coefficient is $(0.19514)$ and (1.19771) respectively. This means that the total equity to total assets increases Islamic banks (ROA) by $19.514 \%$ and (ROE) by $119.771 \%$ when it is increased by $1 \%$ keeping other variables fixed. This supports that profitable banks remain well capitalized or well capitalized banks enjoy access to cheaper (less risky) sources of funds with consequent improvement in profit rates (Bourke, 1989). These findings are consistent with previous studies by (Bashir \& Hassan 2000; Bashir, 2003; Sufian \& Habibullah, 2009; Vong \& Chan, 2009 ) providing support to the argument that well capitalized banks face lower costs of going bankrupt, thus lowers their funding cost, or that they have lower needs for external funding resulting in higher profitability. Nevertheless, strong capital structure is essential for banks in emerging economies since it provides additional strength to withstand financial crises and increased safety for depositors during unstable macroeconomic conditions.

3) The bank financial structure represented by bank size measured by logarithmic of total assets (LTA): The regression results show that the log total assets (LTA) has a positive and significant impact on both return on assets (ROA) and return on equity (ROE). The value of the coefficient is $(0.01877)$ and $(0.17498)$ respectively. The result is consistent with result of the study of (Alkassim, 2005). The result suggests that the larger the bank is, the more profitable the bank will be, purely because of the economies of scale arguments. Shaffer (1985) attributes to the increase of the size of the bank, cost can be reduced and therefore, performance can be improved. In the same context Mathur and Keynon (1998) state that organization size may have a positive impact on the 
organization financial performance, because big organizations can get more loans due to their sizes. This may help the large organizations to reduce the cost of inputs have an access to new input markets. (Hill, 1985) wrote that Large firms mainly can get an access to lowest cost finance.

4) The impact of bank characteristics represented by liquidity measured by total loans to total deposit (TLTD): The regression results show that the total loans to total deposit (TLTD) has a negative insignificant impact on return on assets (ROA) and a negative significant impact return on equity (ROE). The value of the coefficient is (0.0062) and (-0.1107) respectively. Liquidity affects the cost of capital (O'regan, 2001; Friedlob \& Schleifer, 2003) that immediately affects firms' performance by depending on firm's own liquidity through access to loans at preferential rates of interest. Liquidity, measured by current ratio is considered as a powerful tool in predicting incoming cash crises, where it reflects companies' abilities on surviving and future growing depending on their liquidity power. While a high value of the liquidity however does not necessarily imply greater liquidity, it may suggest that funds are not being efficiently employed (Melicher \& Norton, 2003).

5) The impact of macroeconomic factors measured by the logarithm of Amman stock exchange index (LSMI): The study used the logarithmic of stock market index to be more consistent. The regression results show that the stock market index has a positive significant impact at $1 \%$ level on return on assets (ROA) and (ROE). The value of the coefficient is (.01553) and (.18384) respectively. This refers to the stock market which reflects the economic environment in the country which reflects the economic situation whether it has an expansion or recession case. In addition, stock exchange can defeat the firm problem between principal and agent which pressure firm's mangers to effort more efficiently and to maximize their firms' profit and achieve the owners goals. Mayer and Alexander (1991).

6) The impact of macroeconomic factors measured by the logarithm of constructions licensed square meters (LCLSM)): The study used the logarithmic of constructions licensed square meters to be more consistent. The regression results show that the constructions licensed square meters have a positive significant impact on return on assets (ROA) and (ROE). The value of the coefficient is (0.0299) and (.3089) respectively. The higher growth in this active sector leads to a high demand for Islamic financing mainly by Murabaha and Ijarah and for both households and investors and this will lead to a higher profitability.

7) The impact of macroeconomic factors measured by broader money supply growth (GM2): the study used the growth M2 ratio. The regression results indicate that the growth of money supply (GM2) has a positive significant impact on return on assets (ROA) while it has a positive insignificant impact on (ROE). The value of the coefficient is (0.02968) and (.00127) respectively. Generally, the higher the growth of money supply (GM2) the banks will have more money to lend out. So, it leads to higher profitability.

The values of R-squared is equal to (. 94793) for (ROA) and (0.92917), for (ROE) this means that $94.793 \%$ and $92.917 \%$ respectively of the total variation in the level of ROA and ROE for Islamic banks in Jordan is attributed to the variation in the internal variables and the variation in external variables.

\section{Conclusions}

The aim of this study is to investigate the impact of internal and external variables on Islamic banks' profitability in Jordan. The internal variables are included capital adequacy ratio (TETA), bank size (LTA), liquidity (TLTA), leverage (TDTA) while external variables are logarithmic of stock market index (LSMI), logarithmic of constructions licensed square meters (LSMI) and money supply growth (GM2) The Return on Asset (ROA) and the return on equity are taken as a measurement of profitability. The empirical results indicate that there are significant differences in the determinants of profitability measures. A number of conclusions can be drawn from the current study:

1) Bank characteristics represented by Leverage and measured by total deposits to total assets (TDTA) has a negative and significant impact on both return on assets (ROA) and return on equity (ROE). This may be attributed to the fact that banks are more exposed to credit risk and they may face more decrease in their profitability.

2) Bank characteristics represented by Capital adequacy has a positive and significant impact on both return on assets (ROA) and return on equity (ROE). Banks with high owned capital will achieve high profits because they use a cheaper source of financing and low risk financing sources.

3) Bank characteristics represented by liquidity has a negative insignificant impact on return on assets (ROA) while it has a negative significant impact on return on equity (ROE). Liquidity is an important thing for banks to meet their obligations but it also means that if it is too high this means banks are not working efficiently which leads to a decrease in Islamic banks profitability. 
Table 4. The impact of macroeconomic factors and banks characteristics on Jordanian Islamic banks profitability (fixed effects model)

\begin{tabular}{|c|c|c|}
\hline \multicolumn{3}{|c|}{ Dependent variables } \\
\hline Independent & ROA & ROE \\
\hline Variables & Coefficient & Coefficient \\
\hline & -0.0203 & -0.1505 \\
\hline TDTA & $(-5.3698)^{* * *}$ & $(-3.7444)^{* * *}$ \\
\hline \multirow{3}{*}{ TLTD } & -0.0062 & -0.1107 \\
\hline & $(-1.3267)$ & $(-2.0664)^{* *}$ \\
\hline & 0.01553 & 0.18384 \\
\hline \multirow[t]{2}{*}{ LSMI } & $(3.55201)^{* * *}$ & $(3.62514)^{* * *}$ \\
\hline & 0.0299 & 0.3089 \\
\hline \multirow[t]{2}{*}{ LCLSM } & $(2.3638)^{* *}$ & $(1.8835)^{*}$ \\
\hline & 0.19514 & 1.19771 \\
\hline \multirow[t]{2}{*}{ TETA } & $(6.97935)^{* * *}$ & $(4.88184)^{* * *}$ \\
\hline & 0.01877 & 0.17498 \\
\hline \multirow[t]{2}{*}{ LTA } & $(2.97048)^{* *}$ & $(2.16834)^{* *}$ \\
\hline & 0.02968 & 0.00127 \\
\hline GM2 & $(1.86288)^{*}$ & $(0.8561)$ \\
\hline $\mathrm{R}^{2}$ & .94793 & 0.92917 \\
\hline $\mathrm{R}$ & 0.90888 & 0.87605 \\
\hline \multirow[t]{2}{*}{ S.E. } & 0.00168 & 0.00197 \\
\hline & 31.209 & 22.48865 \\
\hline \multicolumn{3}{|l|}{$\mathrm{F}$} \\
\hline $\mathrm{P}$ & 0.000001 & 0.000005 \\
\hline Banks & 2 & 2 \\
\hline NO & 22 & 22 \\
\hline
\end{tabular}

Note (a) $(*),(* *),(* * *)$ indicate significance at the $10 \%, 5 \%$ and $1 \%$ level respectively. $t$ statistics between parenthesis.

So in general the regression results show that the bank characteristics measured by leverage, capital adequacy and liquidity are considered as a good determinant for Islamic banks profitability.

4) Bank Financial Structure represented by bank size has a positive and significant impact on both return on assets (ROA) and return on equity (ROE). As a bank size increases the cost will be reduced and the profitability will increase so bank size is a good determinant for Islamic banks profitability.

5) The regression results shows that the macroeconomic factors represented by Amman stock exchange index, money supply growth and the construction licensed square meters have a positive and significant impacts on both return on assets and return on equity, this is because all of these variables reflect the economic environment whether the economy is working well or not and is directly reflected on Islamic banks as well as other sectors in the economy. So this indicates that that the macroeconomic factors measured by Amman stock exchange index, money supply growth and the construction licensed square meters are a good determinants for Islamic banks financial performance.

The present study suggests that the Islamic banks in Jordan have to increase their size and capital adequacy in order to increase their profitability and to interact well with the economic environment. The present study also suggests that future analysis of the Islamic banks profitability determinants should use more internal and external 
variables.

\section{References}

Abdel-Hameed, M. B. (2003). Determinants of Profitability In Islamic Banks: Some Evidence From The Middle East, Islamic Economic Studies (1st ed.). Capital Markets and Financial Intermediation. Cambridge University press.

Allen, F. (1993). Stock markets and resource allocation. In Mayer, C., \& Vives, X. (Eds.).

Asma, I. F., Adli, A., \& Noor, T. (2011). Determinant of Islamic banking institutions' profitability in Malaysia. Word Applied Sciences Journal, 12.

Athanasoglou, P., Brissimis, S. N., \& Delis, M. D. (2005). Bank-specific, industry-Specific and macroeconomic determinants of bank profitability. Working Paper, 25, Bank of Greece.

Baltagi, B. H. (2000). Econometric Analysis of Panel Data (2nd ed.). New York: John Wiley \& Sons.

Booth, L., \& Seen Clearly, W. (2008). Introduction to Corporate Finance (2nd ed.). Wiley.

Bourke, P. (1989). Concentration and other determinants of bank profitability in Europe. North America and Australia. Journal of Banking and Finance, 13, 65-67. http://dx.doi.org/10.1016/0378-4266(89)90020-4

Faure-Grimaud, A., \& Gromb, D. (2004). Public trading and private incentives. Review of Financial Studies, 17, 985-1014. http://dx.doi.org/10.1093/rfs/hhh002

Friedlob, G. T., \& Schleifer, L. L. (2003). Essentials of financial analysis. Hoboken, New Jersey: John Whiley \& Sons.

Haron, S. (2004). Determinants of Islamic banks profitability. Global Journal of Finance and Economics, 1(1).

Hester, D. D., \& Zoellner, J. F. (1966). The relation between bank portfolios and earnings: an econometric analysis. Review of Economics and Statistics, 48, 372-386. http://dx.doi.org/10.2307/1924615

Hill, C. W. (1985). Diversified growth and competition: The experience of twelve large UK firms. Applied Economics, 17, 827-847. http://dx.doi.org/10.1080/00036848500000039

Izhar, H., \& Mehmet, A. (2007). Estimating the profitability of Islamic banking: evidence from bank muamalat Indonesia. Review of Islamic Economics, 11(2), 17-29.

Jensen, M. (1989). The eclipse of the public corporation. Harvard Business Review, 67, 61-74.

Khan, M., \& Jain, P. (2007). Financial management: text, problems and cases (5th ed.). Tata McGraw-Hill.

Maali, B., Casson, P., \& Napier, C. (2006). Social reporting by Islamic Banks. Accounting Foundation, The $\begin{array}{llll}\text { University } & \text { of } & \text { Sydney. } & \text { from }\end{array}$ http:/www.tehrantimes.com/.../106521-iran-holds-427-of-total-global-islamic-banking-assets Cached17-4-2013.

Manez, J. A., Rochina, M. E., \& Sanchis, J. A. (2004). The decisionto export: a Panel Data Analysis for Spanish manufacturing. Applied Economics Letters, 11, 669-673. http://dx.doi.org/10.1080/1350485042000236601

Mathur, S. S., \& Keynon, A. (1998). Creating value: Shaping tomorrow's business. Oxford: Butterworth Heinemann.

Mayer, C., \& Alexander, I. (1991). Stock markets and corporate performance: Acomparison of quoted and unquoted companies. CEPR discussion paper No. 571.

Molyneux, P., \& Thornton, J. (1992). Determinants of European bank profitability: a note. Journal of Banking and Finance, 16(6), 1173-1178.

Mullineaux, D. J. (1978). Economies of scale and organizational efficiency in banking: a profit-function approach. Journal of Finance, 33, 259-280.

Noor, M. A., \& Ahmad, N. H. (2011). Relationship between Islamic banking profitability and determinants of efficiency. The IUP Journal of Managerial Economics, IX(3), 43-87.

Shaffer, S. (1985). Competion, economies of scale, and diversity of firm sizes. Applied Economics, 17, 467-76. http://dx.doi.org/10.1080/00036848500000051

Smirlock, M. (1985). Evidence on the non relationship between concentration and profitability in banking. Journal of Money, Credit and Banking, 17, 69-83. http://dx.doi.org/10.2307/1992507

Sudin, H., \& Wan, N. (2009). Islamic Finance and Banking System, Malaysia, Sdn, Bhd: McGraw-Hill. 
Sufian, F., \& Habibullah, M. S. (2009). Bank specific and macroeconomic determinants of bank profitability: empirical evidence from the China banking sector. Frontiers of Economics in China, 4(2), 274-291. $\mathrm{http}: / / \mathrm{dx}$. doi.org/10.1007/s11459-009-0016-1

Torres-Reyna, O. (2007). Panel Data Analysis: Fixed and Random Effects using STATA. Princeton University. Retrieved from http://dss.princeton.edu/training, accessed on 18/07/2012

Vong, A. P. I., \& Chan, H. S. (2009). Determinants of bank profitability in Macao. Macau Monetary Research Bulletin, 12(6), 93-113.

\section{Copyrights}

Copyright for this article is retained by the author(s), with first publication rights granted to the journal.

This is an open-access article distributed under the terms and conditions of the Creative Commons Attribution license (http://creativecommons.org/licenses/by/3.0/). 